\title{
Potensi Ekstrak Kasar Teh Hitam (Camellia sinensis O.K. var. Assamica) sebagai Pewarna (Dye) pada Pembuatan Sela Surya Tersensitisasi (SSPT)
}

\author{
Oki Deskawi $^{1}$, Rachmawati Ningsih ${ }^{1}$, Novi Avisena ${ }^{2}$, Erna Hastuti ${ }^{2}$ \\ ${ }^{1}$ Jurusan Kimia Fakultas Sains dan Teknologi UIN Maulana Malik Ibrahim Malang \\ ${ }^{2}$ Jurusan Fisika Fakultas Sains dan Teknologi UIN Maulana Malik Ibrahim Malang \\ Email: dna_dvebrian@yahoo.co.id
}

\begin{abstract}
Has done research on the manufacture of dye sensitized solar cells by utilizing the crude extract of black tea (Camellia sinensis var O.K. Assamica). This study aims to determine the potential of black tea extract as a dye in dye sensitized solar cell manufacturing. This study includes several stages: sample preparation of black tea, black tea sample extraction in a mixture of acetic acid: methanol: distilled water $(4: 25: 21)$, analysis of the crude extract of black tea using UV-Vis, color density analysis using a color reader, testing DSSC obtained by measuring voltages and currents strong produced under conditions halogen lamp illuminated with a light intensity of $4.488 \mathrm{Watt} / \mathrm{m}^{2}$, the identification number of the crude extract of pigments by TLC analytical. The results of the characterization black tea extract is flavonoids. That it contains theaflavins shown with a maximum wavelength $273 \mathrm{~nm}$. Color of black tea using a color reader testing showed reddish yellow (orange) with the color density reached $78,3 \%$. Voltage maximum and maximum current strength produced by $107,3 \mathrm{mV}$ and 2.13 x $10^{-3} \mathrm{~mA}$. The efficiency of the resulting solar cell system by $1,26 \times 10^{-2 \%}$. The results of the identification of the amount of pigment produced 8 spot with eluent ethyl acetate: formic acid: distilled water.
\end{abstract}

Keywords: Dye sensitized solar cells, dye (dye), theaflavin

Abstrak
Telah dilakukan penelitian mengenai pembuatan Sel surya pewarna tersensitisasi dengan memanfaatkan ekstrak kasar teh hitam (Camellia sinensis O.K. var. Assamica). Penelitian ini bertujuan untuk mengetahui potensi ekstrak teh hitam sebagai pewarna pada pembuatan sel surya pewarna tersensitisasi. Penelitian ini meliputi beberapa tahapan yaitu: preparasi sampel teh hitam, ekstraksi sampel teh hitam dalam campuran asam asetat:metanol:aquades (4:25:21), analisis ekstrak kasar teh hitam menggunakan UV-Vis, analisis kepekatan warna menggunakan color reader, pengujian SSPT diperoleh melalui pengukuran tegangan dan kuat arus yang dihasilkan pada kondisi disinari lampu halogen dengan intensitas cahaya sebesar 4,488 Watt $/ \mathrm{m}^{2}$, identifikasi jumlah pigmen ekstrak kasar dengan KLT analitik. Hasil karakterisasi bahwa ekstrak teh hitam merupakan golongan senyawa flavonoid. Adanya kandungan theaflavin ditunjukan dengan panjang gelombang maksimum $273 \mathrm{~nm}$. Warna teh hitam dari pengujian menggunakan color reader menunjukkan warna kuning kemerahan (oranye) dengan tingkat kepekatan warna mencapai 78,3\%. Voltase maksimum dan kuat arus maksimum yang

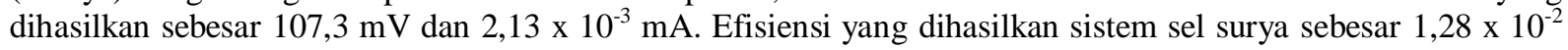
$\%$. Hasil identifikasi jumlah pigmen menghasilkan 8 spot dengan eluen etil asetat : asam format : akuades.

Kata kunci: Sel surya pewarna tersensitisasi, zat warna (dye), theaflavin

\section{PENDAHULUAN}

Konsumsi listrik Indonesia setiap tahunnya terus meningkat sejalan dengan peningkatan kebutuhan, listrik dikemudian hari yang diperkirakan dapat tumbuh ratarata $6,5 \%$ per tahun hingga tahun 2020 (Harjono, 2007). Dengan konsumsi listrik yang cukup besar ini terdapat kendala dalam proses produksinya, mengingat sebagaian besar dari bahan bakar yang dimanfaatkan oleh pembangkit listrik di
Indonesia adalah bahan bakar fosil. Listrik yang diproduksi dengan memanfaatkan bahan bakar fosil memerlukan pemilihan teknologi yang efisien, ramah lingkungan dengan mempertimbangkan cadangan energi dan sedapat mungkin memanfaatkan sumber energi yang terbarukan. Pemilihan teknologi pembangkit listrik yang efisien dan ramah lingkungan diprioritaskan seperti pada pemanfaatan batu bara, tenaga air, dan 
sinar matahari (Boedoyo dan Sugiyono, 2000).

Matahari merupakan sumber kehidupan, baik hewan maupun tumbuhan secara tidak langsung memanfaatkan energi dari matahari untuk kelangsungan hidupnya. Allah SWT menciptakan matahari untuk membantu tumbuhan membuat makanan dengan cahayanya melalui proses fotosintesis. Dari hasil proses fotosintesis tersebut manusia dan hewan mendapatkan makanan, sebagaimana firman Allah SWT dalam surah az Zumar ayat 5 (Dyayadi, 2008): "Dia menciptakan langit dan bumi dengan (tujuan) yang benar, Dia menutupkan malam atas siang dan menutupkan siang atas malam dan menundukkan matahari dan bulan, masingmasing berjalan menurut waktu yang ditentukan, ingatlah Dialah yang Maha Perkasa lagi Maha Pengampun."

Pemanfaatan energi surya menjadi listrik adalah sebuah sumber energi alternatif yang terbarukan. Energi surya yang memasuki atmosfer memiliki kerapatan daya rata-rata sebesar $1,2 \mathrm{~kW} / \mathrm{m}^{2}$, namun hanya sebesar $560 \mathrm{~W} / \mathrm{m}^{2}$ yang diserap bumi. Berdasarkan angka di atas, maka energi surya yang dapat dibangkitkan untuk seluruh daratan Indonesia yang mempunyai luas \pm 2 juta $\mathrm{km}^{2}$ adalah sebesar 5.108 MW (Nitya dan Kusuma, 2005).

Keanekaragaman flora yang ada di wilayah Indonesia memiliki potensi sebagai pewarna (dye) dalam SSPT. Telah banyak jenis ekstrak tumbuhan yang telah digunakan sebagai fotosentizer pada sistem sel surya tersensitisasi pewarna. pada penelitian kali ini yang akan digunakan sebagai pewarna adalah ekstrak kasar dari teh hitam (Camellia sinensis O.K. var Assamica).

Metode pengambilan ekstrak teh hitam dengan metode ekstraksi maserasi menggunakan pelarut campuran yaitu metanol, akuades, dan asam asetat (25:21:4). Hasil maserasi tersebut dikarakterisasi

menggunakan spektofotometer UV-Vis, dan color reader untuk mengetahui tingkat kepekatan ekstak dye yang dihasilkan, sedangkan untuk mengidentifikasi senyawa aktif yang ada dalam ekstrak kasar teh hitam dilakukan identifikasi golongan senyawa flavonoid menggunakan uji fitokimia untuk penguatan dilakukan analisis menggunakan kromatografi lapis tipis. Kemudian membuat prototipe sel surya tersebut menggunakan variasi lama perendaman elektroda $\mathrm{TiO}_{2}$ pada dye dengan lama perendaman 10 menit, 1 jam, 24 jam, dan 48 jam kemudian diukur tegangan dan kuat arus yang dihasilkan menggunakan multimeter dengan iluminasi cahaya lampu halogen. Tujuan Penelitian ini adalah untuk mengetahui potensi ekstrak kasar teh hitam (Camellia sinensis) sebagai pewarna pada SSPT.

\section{METODE PENELITIAN Pelaksanaan Penelitian}

Penelitian ini dilaksanakan di Jurusan Kimia Universitas Islam Negeri Maulana Malik Ibrahim Malang.

\section{Alat dan Bahan Penelitian}

Alat yang digunakan antara lain: erlenmeyer, beaker glass, cawan petri, digital multimeter, light meter, magnetic stirrer hot plate, Shaker, spektrofotometer UV-Vis varian carry 50, transparant conductive oxide (TCO) jenis FTO (flour thin oxide), color reader Minolta CR-10, oven, pipet, scotch tape, blender, ayakan 60 dan 100 mesh, pipet tetes, corong Buchner.

Bahan yang digunakan antara lain: teh hitam (Camellia sinensis) komersil dari koperasi Wonosari Lawang jenis Assamica, metanol, etanol $70 \%$, asam asetat p.a, aseton, tissue, pensil $2 \mathrm{~B}$, titanium oksida $\left(\mathrm{TiO}_{2}\right)$, asetonitril, potasium klorida $(\mathrm{KI})$, akuades, aluminium foil, larutan iodin 10 $\%$, kloroform, PVA (polyvinyl alcohol), asam klorida $2 \mathrm{M}$, serbuk logam $\mathrm{Mg}$, asam 
format, plat KLT $\mathrm{F}_{254}$, etil asetat, asam format, amoniak.

\section{PROSEDUR PENELITIAN}

\section{Preparasi Sampel}

Teh hitam dihaluskan menggunakan blender, kemudian diayak dengan ukuran antara 60-100 mesh. Hasil ayakan yang dipakai adalah yang tertahan di ayakan 100 mesh.

\section{Ekstraksi Maserasi Teh Hitam (Camellia sinensis)}

Sampel teh hitam yang halus ditimbang sebanyak 10 gram kemudian dimasukkan kedalam erlenmeyer $250 \mathrm{~mL}$. Serbuk teh hitam kemudian direndam dengan campuran pelarut $42 \mathrm{ml}$ akuades, 50 $\mathrm{mL}$ metanol, dan $8 \mathrm{~mL}$ asam asetat dalam erlenmeyer $250 \mathrm{~mL}$, kemudian diaduk dengan menggunakan shaker dengan kecepatan $130 \mathrm{rpm}$ (rotation per minutes) selama 5 jam (Hartini, 2004). Setelah itu ekstrak disaring dengan menggunakan corong vaccum Buchner. Hasil ekstrak yang didapat dipindahkan pada botol gelap dan terhindar dari sinar matahari secara langsung (Septina, Fajarisandi, Aditia, 2007).

\section{Pembuatan Pasta $\mathrm{TiO}_{2}$}

Sebanyak 0,5 gram polivinil alkohol (PVA) dilarutkan dengan $5 \mathrm{~mL}$ akuades didalam beaker glass $100 \mathrm{~mL}$, kemudian dipanaskan pada temperatur $80 \quad{ }^{\circ} \mathrm{C}$ menggunakan hot plate sambil diaduk. Suspensi ini akan berfungsi sebagai binder dalam pembuatan pasta. Suspensi diambil sebanyak $\pm 0,1 \mathrm{~mL}$ dan ditambahkan kedalam mortar yang berisi 1 gram bubuk $\mathrm{TiO}_{2}$, kemudian diaduk sampai terbentuk pasta yang baik untuk dilapiskan (Septina, Fajarisandi, Aditia, 2007).

\section{Pelapisan $\mathrm{TiO}_{2}$ Pada Kaca Substrat}

Kaca substrat (kaca konduktif FTO) dengan ukuran $2 \times 2 \mathrm{~cm}$ dicuci dengan detergen kemudian dibasuh dengan etanol pada bagian konduktif untuk menghilangkan kotoran yang ada. Scotch tape direkatkan pada sisi kaca substrat, sehingga sisi konduktif hanya tersisa $1 \times$ $1,5 \mathrm{~cm}$.

Untuk meratakan pasta $\mathrm{TiO}_{2}$ yang dilapiskan pada kaca substrat, maka dipergunakan teknik doctor blade dengan bantuan batang gelas pengaduk. Lapisan $\mathrm{TiO}_{2}$ kemudian dikeringkan dengan cara dianginkan selama 15 menit. Setelah lapisan $\mathrm{TiO}_{2}$ kering, schotch tape diambil kemudian dipanaskan pada suhu $450{ }^{\circ} \mathrm{C}$ selama 30 menit pada hotplate.

\section{Pembuatan Larutan Elektrolit}

Larutan elektrolit iodida/triiodida dibuat dengan prosedur sebagai berikut: Dicampurkan 0,8 gram $(0.5 \mathrm{M})$ kalium iodida (KI) kedalam $10 \mathrm{~mL}$ asetonitril (Lampiran 2.4) kemudian diaduk. Dicampurkan 0,127 gram $(0,05 \mathrm{M})$ iodin $\left(\mathrm{I}_{2}\right)$ kedalam $10 \mathrm{~mL}$ asetonitril (Lampiran 2.3). Kedua larutan kemudian dicampurkan dan diaduk hingga homogen. Larutan disimpan dalam botol gelap dan tertutup rapat (Septina, Fajarisandi, Aditia, 2007).

\section{Pembuatan Counter Elektroda (Karbon)}

Sebagai sumber karbon digunakan grafit dari pensil 2B "faber castell". Grafit dilapiskan pada kaca FTO pada bagian konduktifnya dengan cara mengarsir grafit pada FTO kemudian dipanaskan pada suhu $450{ }^{\circ} \mathrm{C}$ selama 10 menit agar grafit membentuk kontak yang baik sesama partikel karbon dan FTO.

\section{Analisis Ekstrak Teh Hitam menggunakan Spektrofotometer UV-Vis} Larutan hasil ekstraksi yang diperoleh diambil sebanyak 1 tetes dimasukkan kedalam beaker glass $100 \mathrm{~mL}$ kemudian dilarutkan dengan pelarut campuran metanol, akuades, dan asam asetat dan dihomogenkan kemudian dimasukkan ke dalam kuvet dan diukur pada panjang gelombang 200-800 nm kemudian diamati panjang gelombang maksimumnya. Blangko yang digunakan 
adalah campuran metanol, akuades, dan asam asetat dengan perbandingan (24:21:4) tanpa penambahan larutan hasil ekstraksi (Arishandy, 2010).

\section{Analisis Kepekatan Warna Ekstrak Dye menggunakan Color Reader}

Filtrat hasil maserasi diambil sebanyak $5 \mathrm{~mL}$, kemudian dimasukkan dalam kuvet. Color reader mengukur sinar dengan cara merefleksikan dan mengkonversinya ke set koordinat seperti L, a*, dan $\mathrm{b}^{*}$. Koordinat-koordinat ini menunjukkan sistem tiga dimensi yang mengandung semua warna. Nilai L mewakili lightness, yaitu 0 untuk hitam dan 100 untuk putih, axis a* menunjukkan intensitas warna merah (+) atau hijau (-), axis $b^{*}$ menunjukkan intensitas warna kuning (+) atau biru (-) (Prayogo, 2010).

\section{Pembuatan dan Pengujian Sel Surya} Pewarna Tersensitisasi dengan Dye Ekstrak Teh Hitam

Dua buah elektroda $\mathrm{TiO}_{2}$ pada substrat kaca FTO direndam di dalam larutan ekstrak kasar teh hitam masingmasing selama 10 menit, 1 jam, 24 jam dan 48 jam. Kemudian lapisan $\mathrm{TiO}_{2}$ dikeluarkan dari larutan dye ekstrak kasar teh hitam dan dibilas pertama kali dengan aquades lalu dengan etanol dan dikeringkan dengan kertas tisu. Lapisan $\mathrm{TiO}_{2}$ yang telah direndam di dalam larutan ekstrak kasar teh hitam disebut $\mathrm{TiO}_{2}$ tersensitisasi dye. Setelah itu larutan elektrolit polimer diteteskan di atas $\mathrm{TiO}_{2}$ tersensitisasi dye, lalu ditutup dengan elektroda lawan (counter electrode) berupa kaca FTO yang telah dilapisi dengan arsiran karbon.

Sel surya yang dihasilkan diukur karakteristik arus dan tegangan (I dan V) dengan merangkainya dengan sebuah multimeter (Gambar 1). Sumber cahaya lampu halogen dengan intensitas 4,488 Watt $/ \mathrm{m}^{2}$ diarahkan tegak lurus terhadap permukaan sel surya.

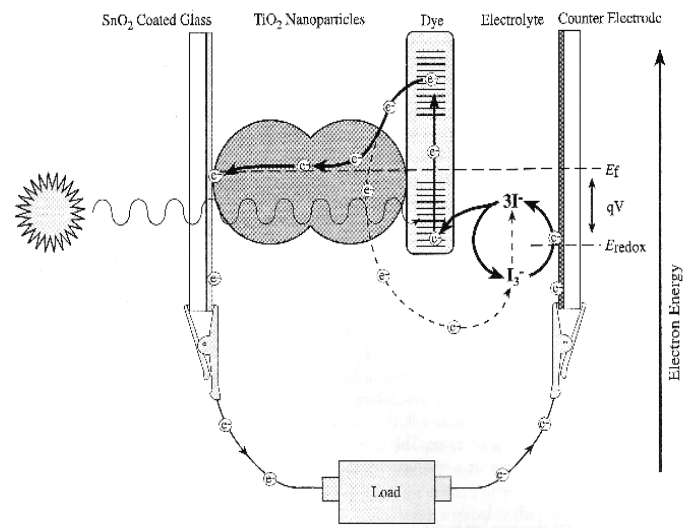

Gambar 1. Rangkaian sel surya

\section{Uji Golongan Senyawa Flavonoid pada Ekstrak Teh Hitam Uji menggunakan HCl 2 M}

Ekstrak kasar teh hitam diambil sebanyak $0,5 \mathrm{~mL}$ dimasukkan ke dalam tabung reaksi kemudian dididihkan dengan 1-2 $\mathrm{mL} \quad \mathrm{HCl} 2 \mathrm{M}$. Jika ekstrak menunjukkan warna coklat kuning, maka positif mengandung flavonoid (Hidayati, 2009).

\section{Uji menggunakan Logam Mg}

Ekstrak kasar teh hitam diambil 0,5 $\mathrm{mL}$ kemudian dimasukkan kedalam tabung reaksi kemudian dilarutkan menggunakan 1-2 mL metanol $50 \%$ panas, kemudian ditambahkan logam $\mathrm{Mg}$ dan 4-5 mL tetes $\mathrm{HCl}$ pekat. Jika larutan berwarna merah atau jingga maka menunjukkan adanya golongan senyawa flavonoid (Husnah, 2009).

\section{Identifikasi Jumlah Pigmen dengan KLT (Kromatografi Lapis Tipis)}

Pada pemisahan dengan KLT analitik digunakan plat silika gel GF254 yang sudah diaktifasi dengan pemanasan dalam oven pada suhu $100{ }^{\circ} \mathrm{C}$ selama \pm 15 menit. Masing-masing plat dengan ukuran 1 $\mathrm{x} 10 \mathrm{~cm}^{2}$. Ekstrak teh ditotolkan pada jarak $1 \mathrm{~cm}$ dari tepi bawah plat dengan pipa kapiler. Kemudian dikeringkan dan dielusi dengan fase gerak etil asetat:air:asam format $\quad(18: 1: 1) ; \quad(50: 4: 10), \quad$ Metanol: 
kloroform (1:39); (1:9), Etil asetat: asam format: asam asetat: akuades (100:11:11:26) (Markham dan Andersen, 2006). Setelah gerakan larutan pengembang sampai pada garis batas, elusi dihentikan. Noda-noda pada permukaan plat diuapkan dengan uap amoniak sambil diperiksa di bawah sinar UV pada panjang gelombang maksimum $254 \mathrm{~nm}$.

\section{HASIL DAN PEMBAHASAN Preparasi Sampel}

Sampel dengan penampang permukaan lebih luas akan mempercepat proses ekstraksi dan membuat kontak antara sampel dan pelarut semakin maksimal. Teh hitam komersil "Teh Wonosari" kualitas lokal yang didapatkan dari koperasi Wonosari Lawang diblender sampai halus kemudian diayak dengan menggunakan ayakan dengan ukuran 60-100 mesh. Penghalusan sampel yang dilakukan untuk menghomogenkan ukuran dari sampel dan memperbesar kontak antara bidang sampel dengan pelarut sehingga mempermudah proses ekstraksi komponen aktif yang ada pada sampel teh hitam dan dapat memaksimalkan proses ekstraksi.

\section{Ekstraksi Sampel}

Ekstraksi teh hitam menggunakan metode maserasi dengan pelarut campuran yaitu metanol, akuades, dan asam asetat dengan perbandingan (25:21:4) (Maddu, Zuhri, Irmansyah, 2007). Penggunaan pelarut campuran ini dimaksudkan agar senyawa theaflavin dan thearubigin yang terdapat dalam teh hitam dapat terekstrak ke dalam pelarut yang memiliki kepolaran yang sama dengan senyawa tersebut. Metode maserasi ini dipakai karena prosesnya mudah dan tidak menggunakan suhu tinggi yang dimungkinkan dapat merusak senyawa-senyawa kimia yang terdapat pada sampel teh hitam. Rusaknya senyawa pada ekstrak akan mempengaruhi kegunaan ekstrak teh hitam sebagai fotosensitizer pada pembuatan sel surya pewarna tersensitisasi (SSPT).

Hasil ekstraksi yang telah didiamkan selama 24 jam berwarna coklat kemerahan. Ekstrak selanjutnya disaring menggunakan corong Buchner agar terpisah antara filtrat dengan residu selanjutnya didapatkan ekstrak kasar teh hitam. Ekstrak kasar tersebut dipindahkan kedalam botol berwarna gelap yang bagian luarnya ditutup dengan menggunakan alumunium foil.

Penutupan menggunakan aluminium foil yaitu untuk menghindari kontak langsung dengan matahari. Kontak secara langsung dengan cahaya mataharri dapat mengakibatkan ekstrak tersebut terdegradasi sebelum dilakukan pengujian pada pembuatan sel surya. Hal ini telah diteliti oleh Khuluq et al. (2007) pada senyawa betasianin yang menyatakan cahaya yang diterima senyawa akan menghasilkan energi panas.

\section{Pembuatan Prototipe Sel Surya Pewarna Tersensitisasi}

Prototipe yang telah dibuat kemudian diukur nilai kuat arus - tegangan (I-V). Pengujian SSPT dilakukan di Laboratorium Optik Jurusan Fisika UIN Maulana Malik Ibrahim Malang. Sumber cahaya yang digunakan berasal dari lampu halogen yang diarahkan tegak lurus terhadap permukaan sel surya. Intensitas cahaya yang digunakan sebesar 4,488 Watt $/ \mathrm{m}^{2}$, sedangkan SSPT yang diuji memiliki luas $\pm 1,5 \times 10^{-4} \mathrm{~m}^{2}$. Hasil keluaran diukur dengan multimeter digital yang dihubungkan secara seri dengan SSPT. Dari hasil pengukuran didapatkan data tegangan (V) dan arus (I), kemudian dihitung daya $(P)$ dan efisiensi $(\eta)$ dengan menggunakan persamaan :

$$
\eta=\frac{P}{P_{\text {Cahaya }}} \times 100 \%
$$


dengan $\eta$ adalah efisiensi, $P_{\text {cahaya }}$ adalah daya yang digunakan dalam pengujian dan $P$ adalah daya yang dihasilkan oleh SSPT yang merupakan hasil kali antara tegangan (V) dan arus (I). Pengukuran nilai kuat arus, tegangan, dan efisiensi SSPT yang dilakukan pada penelitian ini memberikan hasil yang dapat dilihat pada Tabel 1:

Tabel 1. Pengukuran nilai kuat arus, tegangan, dan efisiensi SSPT

\begin{tabular}{|c|c|c|c|c|c|}
\hline \multirow{2}{*}{ Dye } & $\begin{array}{c}\text { Lama } \\
\text { Perendaman }\end{array}$ & $V(\mathrm{mV})$ & $\mathrm{I}(\mathrm{\mu A})$ & $\mathrm{P}(\mathrm{mIV})$ & $\eta(\%)$ \\
\hline \multirow{4}{*}{$\begin{array}{c}\text { Teh } \\
\text { Hitam }\end{array}$} & $0,167 \mathrm{jam}$ & 25,1 & 1,23 & $4,59 \times 10^{-5}$ & $4,59 \times 10^{-3}$ \\
\cline { 2 - 6 } & $1 \mathrm{Jam}$ & 33 & 2,1 & $6,65 \times 10^{-5}$ & $1,01 \times 10^{-2}$ \\
\cline { 2 - 6 } & $24 \mathrm{Jam}$ & 107,3 & 0,8 & $7,63 \times 10^{-5}$ & $1,27 \times 10^{-2}$ \\
\cline { 2 - 6 } & $48 \mathrm{Jam}$ & 89,2 & 0,7 & $6,06 \times 10^{-5}$ & $9,37 \times 10^{-3}$ \\
\hline
\end{tabular}

Tabel 1. menunjukkan bahwa elektron dari senyawa yang ada pada teh hitam akan mampu mengalirkan elektronnya saat dikenai sinar sehingga terjadi eksitasi dari keadaan HOMO (Highest Occupied Molecular Orbital) menjadi LUMO (Lowest Unoccupied Molecular Orbital). Elektron membutuhkan energi dengan besar tertentu agar dapat digunakan untuk tereksitasi kemudian elektron tersebut masuk kedalam lapisan $\mathrm{TiO}_{2}$ dan terjadi aliran elektron yang melewati multimeter dan terbaca sebagai kuat arus dan tegangan. Kehilangan elektron pada senyawa dye diregenerasi oleh adanya larutan elektrolit.

Nilai efisiensi maksimum Tabel 1 diperoleh dari lama perendaman selama 24 jam yaitu sebesar $1,28 \times 10^{-2} \%$ dengan daya sebesar $8,58 \times 10^{-5} \mathrm{~mW}$. Pada perendaman 48 jam nilai dari efisiensi dan dayanya berkurang hal ini dapat dikarenakan pasta $\mathrm{TiO}_{2}$ yang menempel pada kaca konduktif ikut terlarut pada ekstrak teh hitam. Pada (Gambar 2) berikut menujukkan hubungan antara lama perendaman dengan nilai efisiensi yang dihasilkan pada pengujian sel surya.

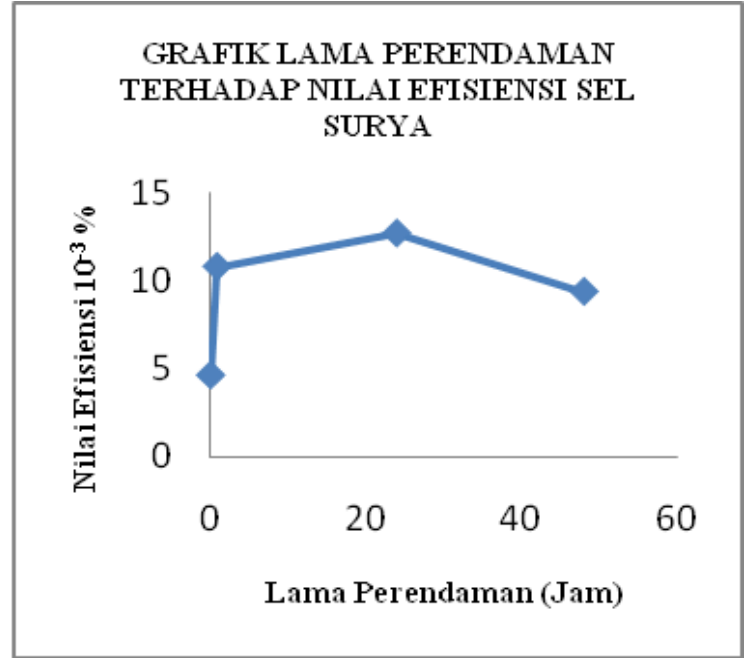

Gambar 2. Pengaruh lama perendaman dengan efisiensi sel surya

Berdasarkan uji statistik ANOVA one-way didapatkan nilai $\mathrm{F}_{\text {hitung }}=49,977>$ $F_{\text {tabel }}(0.05 ; 3 ; 8)=4,07$; Pvalue $=0<\alpha=$ 0,05 , maka dapat dinyatakan bahwa lama perendaman berpengaruh terhadap nilai efisensi yang dihasilkan. Berdasarkan uji BNT dapat diketahui bahwa terdapat notasi huruf yang sama, maka dapat disimpulkan bahwa perlakuan perendaman 1 jam dan 48 jam tidak memiliki perbedaan yang nyata atau dapat dikatakan sama. Perlakuan perendaman 24 jam memiliki nilai beda nyata dari perlakuan pendaman 10 menit, 1 jam, dan 24 jam. Jadi meskipun selisih nilai efisiensi antara perendaman 1 jam dan 24 jam cukup kecil namun hal itu berbeda dan tidak dapat dianggap sama.

\section{Identifikasi Ekstrak Kasar dengan Spektrofotometer UV-Vis}

Ekstrak kasar yang telah didapatkan kemudian diukur menggunakan instrumen UV-Vis Varian Cary 50 pada panjang gelombang $\lambda$ 200-800 nm. Ekstrak kasar dengan campuran pelarut metanol, akuades, dan asam asetat (25:21:4) memiliki warna kekuningan dan memiliki serapan cahaya daerah UV dengan $\lambda_{\max } 273 \mathrm{~nm}$, seperti yang ditunjukkan pada Gambar 3: 


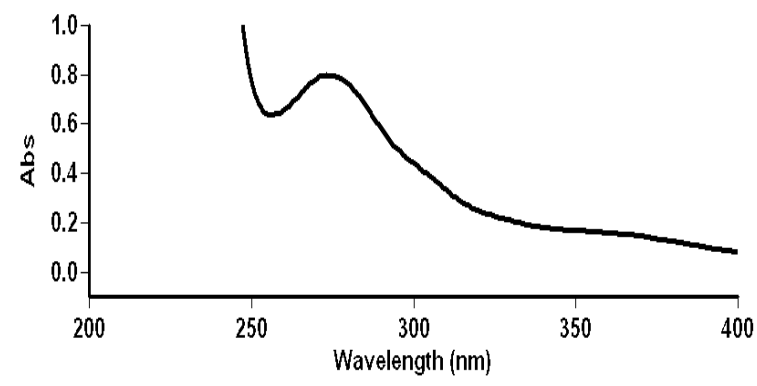

Gambar 3. Spektra ekstrak kasar teh hitam dengan pelarut campuran metanol, akuades, dan asam asetat (25:21:4).

Menurut Markham (1988) bahwa spektrum flavonoid biasanya ditentukan dengan pelarut metanol atau etanol. Spektrum khas terdiri dari dua maksimal pada rentang 240-285 nm (pita II) dan 300$550 \mathrm{~nm}$ (pita I). Menurut Turkoglu et al. (2010) Ekstrak teh hitam dan teh hijau menghasilkan spektra UV yang mirip yaitu antara 200-400 nm dengan puncak disekitar 272 nm. Menurut Tanaka et al. (2001) theaflavin akan menghasilkan 2 puncak yaitu pada $274 \mathrm{~nm}$ dan $378 \mathrm{~nm}$.

\section{Analisis Kepekatan Warna Ekstrak Dye Menggunakan Color Reader}

Color reader mempunyai prinsip parameter pembacaan L, a*, dan $b^{*}$ parameter $\mathrm{L}$ menunujukkan tingkat kecerahan dengan skala 0 (gelap/hitam) sampai 100 (terang/cerah). Nilai $\mathrm{a}^{*}$ menyatakan warna jingga hingga merah dengan skala -100 sampai +100 . Nilai a* negatif menunjukkan warna hijau kebiruan sedangkan nilai positif menunjukkan warna merah keunguan. Nilai $b^{*}$ menunjukkan warna kromatik campuran kuning biru dengan nilai $+b$ dari 0 sampai +60 untuk warna kuning dan nilai -b dari 0 sampai -60 untuk warna biru.

Setelah sampel ekstrak teh hitam dan alat color reader disiapkan, yaitu mengambil $5 \mathrm{~mL}$ ekstrak kemudian dimasukkan kedalam kuvet dan diukur nilai $\mathrm{L}, \mathrm{a}^{*}$, dan $\mathrm{b}^{*}$ menggunakan color reader Minolta CR-10. Hasil pembacaan kepekatan warna ekstrak kasar teh hitam color reader dapat dilihat pada Tabel 2.

Tabel 2. Hasil pengukuran kepekatan warna ekstrak kasar teh hitam

\begin{tabular}{|c|c|}
\hline Kode & Nilai Warna \\
\hline $\mathrm{L}^{*}$ & 21,7 \\
\hline $\mathrm{a}^{*}$ & 6,7 \\
\hline $\mathrm{b}^{*}$ & 7,8 \\
\hline
\end{tabular}

Nilai kecerahan warna (L) menunjukkan tingkat kecerahan ekstrak kasar teh hitam sebesar 21,7 yang diambil dari rentang L adalah 0 (hitam) sampai 100 (putih). Nilai a* positif dengan nilai 6,7 menunjukkan warna ekstrak teh hitam menuju ke merah, sedangkan nilai $b^{*}$ juga menunjukkan nilai positif yaitu 7,8 yaitu menunjukkan warna ekstrak teh hitam menuju ke warna kuning hal ini ditunjukkan pada warna ekstrak yang berwarna kuning kemerahan.

Hal ini diperkuat dari penelitian Scharbert, Holzmann, dan Hofmann (2004) yang menyatakan theaflavin berwarna oranye sedangkan thearubigin berwarna merah kecoklatan. Tingkat kepekatan larutan pada penelitian mencapai 78,3\%. Tingkat kepekatan dari suatu sampel secara kualitatif dapat menyatakan konsentrasi total senyawa atau banyaknya senyawa yang dapat terekstrak dalam pelarut. Pigmen warna (dye) senyawa theaflavin dan thearubigin dari teh hitam dapat digunakan sebagai pewarna alami (dye) pada pembuatan sel surya.

\section{Uji Golongan Senyawa Flavonoid dengan Reagen}

Uji golongan senyawa flavonoid merupakan bagian dari uji fitokimia yang merupakan uji kualitatif kandungan golongan senyawa aktif pada ekstrak tanaman, sehingga dapat diketahui 
golongan senyawa yang terdapat pada ekstrak tersebut. Biasanya uji golongan senyawa aktif dilakukan dalam tabung dengan jumlah sampel yang relatif sedikit. Uji golongan senyawa flavonoid dalam penelitian ini dilakukan dengan uji reagen yang dilanjutkan dengan uji menggunakan kromatografi lapis tipis (KLT) analitik. Uji dengan KLT ini dilakukan untuk mendukung hasil identifikasi senyawa dengan uji reagen.

Tabel 3. Hasil uji kualitatif flavonoid pada ekstrak kasar teh hitam

\begin{tabular}{|c|c|c|}
\hline Uji & Hasil & Standart (warna) \\
\hline Serbuk Mg & + & Coklat kekuningan \\
\hline HCl 2 M & + & Coklat bening \\
\hline
\end{tabular}

Keterangan:

tanda + : terkandung senyawa/warna pekat tanda - : tidak terkandung senyawa/ tidak terbentuk warna

Ekstrak teh hitam pada pelarut campuran metanol, akuades, dan asam asetat menghasilkan warna jingga keruh. Hal ini menunjukkan bahwa ekstrak kasar teh hitam positif flavonoid.

\section{Identifikasi Jumlah Pigmen Ekstrak Teh Hitam dengan KLT Analitik}

Cara yang digunakan dalam identifikasi noda-noda yang terbentuk pada plat KLT dapat dilakukan dengan menggunakan lampu UV (Ultraviolet) dimana beberapa senyawa bahan alam akan berflourosensi yaitu memancarkan cahaya tampak saat disinari dengan sinar UV atau mengabsorpsi sinar UV. Hal ini dikarenakan senyawa bahan alam memiliki gugus kromofor yang khas yang dapat membentuk warna. Panjang sinar UV yang digunakan adalah $254 \mathrm{~nm}$ dan $366 \mathrm{~nm}$. Penampakan noda pada lampu UV $254 \mathrm{~nm}$ dikarenakan adanya daya interaksi antara sinar UV dengan indikator flouresensi yang terdapat pada plat KLT. Pada sinar UV panjang gelombang $366 \mathrm{~nm}$ digunakan untuk menampakkan bercak yang berflouresensi sehingga pada pengamatan terlihat bercak berpendar (memancarkan cahaya). Penampakan noda pada lampu UV $366 \mathrm{~nm}$ adalah karena adanya interaksi antara sinar UV dengan gugus kromofor yang terikat oleh auksokrom yang ada pada noda tersebut.

Penggunaan berbagai macam komposisi eluen dimaksudkan untuk mencari eluen terbaik untuk memisahkan komponen-komponen senyawa flavonoid yang terkandung dalam teh hitam. Pemisahan komponen senyawa dari ekstrak kasar dilakukan menggunakan plat silika gel $\mathrm{F}_{254}$ dengan variasi eluen yaitu, etil asetat : akuades : asam format (18:1:1); (50:10:4), etil asetat : asam format: asam asetat : akuades (100:11:11:26) (Markham dan Andersen, 2006), metanol : kloroform (1:39); (1:9) (Arishandy, 2010) dan kemudian diuap dengan ammonia setelah dilakukan pemisahan.

Eluen etil asetat : asam format : asam asetat : akuades (100:11:11:26) memilik tingkat kepolaran paling polar diantara 5 macam eluen tersebut, namun sebagai eluen pada pemisahan ekstrak kasar teh hitam memberikan hasil yang kurang bagus karena hanya menghasilkan 2 spot. Hal ini dapat terjadi karena kemungkinan kepolaran eluen terlalu polar untuk mampu memisahkan senyawa-senyawa pada ekstrak kasar teh hitam tersebut.

Eluen etil asetat: akuades: asam format (18:1:1) dan (50:4:10) memiliki tingkat kepolaran yang polar jika dibandingkan dengan campuran metanol : kloroform, dan kurang polar dibandingkan dengan eluen etil asetat : asam format : asam asetat : akuades namun mampu memisahkan ekstrak dengan baik. Hal ini dapat terjadi karena tingkat kepolaran untuk pemisahan yang optimal memerlukan tingkat kepolaran yang mendekati sifat dari senyawa-senyawa yang akan dipisahkan.

Eluen etil asetat: akuades: asam format menghasilkan spot yang paling banyak dengan pemisahan yaitu 
menghasilkan 8 spot. Nilai Rf yang dihasilkan yaitu 0,$07 ; 0,13 ; 0,18 ; 0,33$; 0,$38 ; 0,51 ; 0,76 ; 0,83$ (Lampiran 3). Munculnya 8 spot ini tergantung pada kepolaran senyawa terhadap pelarut yaitu interaksi antara molekul senyawa dengan pelarut. Spot dengan nilai $\mathrm{Rf}$ besar merupakan senyawa yang dapat terelusi secara maksimal, sedangkan spot dengan nilai Rf kecil kurang terelusi secara maksimal. Hal ini terjadi karena spot dengan nilai Rf yang kecil memilik faktor distribusi pada fase diamnya lebih besar sehingga lebih lama tertahan pada fase diamnya.

Spot dengan nilai Rf tinggi menunjukkan dapat terelusi scara maksimal karena memiliki tingkat kepolaran yang hampir sama dengan fase geraknya (eluen). Menurut Cakrabuana (2011) golongan senyawa flavonoid hasil KLT analitik, setelah diuap dengan uap ammonia menunjukkan terbentuknya noda berwarna jingga, merah, merah jingga, merah muda, atau ungu. Pada Gambar 4 adalah ilustrasi plat KLT yang telah dielusi dengan eluen dan menghasilkan 8 spot:
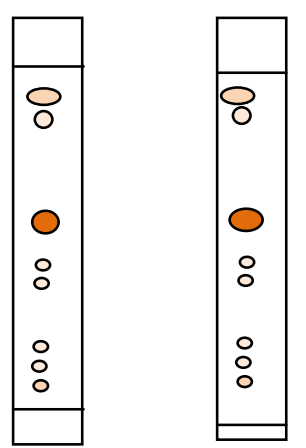

Gambar 4. Hasil KLT eluen (etil asetat:asam format:akuades)

\section{KESIMPULAN}

Hasil spektra UV-Vis ekstrak teh hitam menunjukkan panjang gelombang maksimum sebesar $273 \mathrm{~nm}$. Nilai daya dan efisiensi maksimum yang dihasilkan pada pengujian SSPT yaitu pada lama perendaman 24 jam. Nilai daya sebesar 8,58 x $10^{-5} \mathrm{~mW}$ dan efisiensi sebesar $1,28 \times 10^{-2}$ $\%$. Lama perendaman mempengaruhi besarnya nilai daya dan efisiensi yang dihasilkan pada pengujian SSPT.

\section{DAFTAR PUSTAKA}

Arishandy, D. N. A. T. 2010. Isolasi dan Identifikasi Senyawa Flavonoid dari Daun Sirih Merah (Piper betle L. var Rubrum). Skripsi. Malang: Universitas Islam Negeri Maulana Malik Ibrahim.

Boedoyo, S. dan Sugiyono, A. 2000 Optimasi Suplai Energi dalam Memenuhi Kebutuhan Tenaga Listrik Jangka Panjang di Indonesia. Jurnal Dosen. Institut Sepuluh November.

Cakrabuana, H. 2011. Uji Aktivitas Antioksidan dan Identifikasi Senyawa Aktif Ekstrak Tanaman AntingAnting (Acalypha Indica L.). Skripsi. Jurusan Kimia. Fakultas Sains dan Teknologi. Universitas Islam Negeri Maulana Malik Ibrahim.

Harjono. 2007. Perencanaan kebutuhan energi listrik nasional dengan menggunakan metode ekonometrik. Master Theses. Machine Engineering. RTM 333.793 2 Har p. ITS Library.

Hartini, S. Y. 2004. Daya Antibakteri Campuran Ekstrak Etanol Buah Adas Etanol Buah Adas (Foeniculum vulgare Mill) dan Kulit Batang Pulasari (Alyxia reinwardtii BL). Jurnal Penelitian Fakultas Farmasi. Universitas Gajah Mada.

Hidayati, N. 2009. Uji efektivitas antibakteri ekstrak kasar daun teh (Camellia sinensis L. v. assamica) tua hasil ekstraksi menggunakan pelarut etanol dan aquades. Skripsi. Jurusan Kimia. Fakultas Sains dan Teknologi. Universitas Islam Negeri Maulana Malik Ibrahim. 
Husnah, M. 2009. Identifikasi dan uji aktivitas Golongan senyawa antioksidan Ekstrak kasar buah pepino (solanum muricatum aiton) Berdasarkan variasi pelarut. Skripsi. Jurusan Kimia. Fakultas Sains dan Teknologi. Universitas Islam Negeri Maulana Malik Ibrahim.

Khuluq, A.D. Widjanarko, S.B., Murtini, E.S. 2007. Ekstraksi dan Stabilitas Betasianin Daun Darah (Alternanthera Dentata) (Kajian Perbandingan Pelarut Air:Etanol dan Suhu Ekstraksi). Jurnal Teknologi Pertanian. Vol 8 No.3 Hal. 172-181.

Maddu, A. Zuhri, M. Irmansyah. 2007. Penggunaan Ekstrak Antosianin Kol Merah Sebagai Fotosensitizer Sel Surya $\mathrm{TiO}_{2}$ Nanokristal Tersensitisasi Dye. Makara. Teknologi. vol 11. 2. 78-84.

Markham, K. R. 1988. Cara Mengidentifikasi Flavonoid. terjemahan Kosasih Padmawinata. Bandung: Penerbit ITB.

Markham, K. R dan Andersen, O. M. 2006. Flavonoids, Chemistry, Biochemistry and Applications. United States of America: Taylor \& Francis Group.

Nitya, S. I. G. N dan W. Kusuma. 2005. Kajian energi surya untuk pembangkit tenaga listrik . Jurusan Teknik Mesin. Fakutas Teknik. Universitas Udayana. Vol.4 No.1 Januari - Juni 2005.

Prayogo, B. R. D. 2010. Efektivitas Jenis Pelarut terhadap Kadar Ekstrak Senyawa Antosianin Dari Kelopak Bunga Rosella (Hibiscus sabdariffa). Skripsi. Jurusan Kimia Fakultas SAINTEK Universitas Universitas Islam Negeri Maulana Malik Ibrahim.

Septina, W. Fajarisandi, D. Aditia, M. 2007. Pembuatan Prototipe Solar Cell
Murah dengan Bahan Organikinorganik (Dye-sensitized Solar Cell). Laporan penelitian bidang energi. Institut Teknologi Bandung.

Scharbert, S. Holzmann, A. Hofman, T. 2004. Identification of the Astringent Taste Compounds in Black Tea Infusions by Instrumental Analysis and Human Bioresponse. Journal of Agricultural and Food Chemistry. 2004. 52. 3498-3508.

Tanaka, T. et al. 2001. Two Types of Oxidative Dimerization of the Black Tea Polyphenol Theaflavin. J. Agric. Food Chem. 2001, 49, 5785-5789.

Turkoglu. et al. 2010. In vivo evaluation of black and green tea dermal products against UV radiation. Drug Discoveries \& Therapeutics. 2010; 4(5):362-367. 